\title{
Case Study on the Biopsychosocial Impacts and Coping Behaviors among Victims of Female Sexual Violence in Sukoharjo, Central Java
}

\author{
Isna Rahmawati Retnaningsih'), Argyo Demartoto²), Eti Poncorini3) \\ 1)Masters Program in Public Health, Sebelas Maret University \\ 2)Department of Political and Social Science, Sebelas Maret University \\ 3)Department of Public Health, Faculty of Medicine, Sebelas Maret University
}

\begin{abstract}
Background: Sexual violence on women is a serious social problem. It may cause various impacts including biological, reproductive, psychological, and social impacts. There is a need for behavioral change to deal with the impact of sexual violence. This study aimed to explore the biopsychosocial impacts and coping behaviors among female sexual violence victims.

Subjects and Method: This was a qualitative descriptive research using case study method. The study was conducted in Sukoharjo from 15 June to 25 July 2017. Key informants were included female sexual violence victims and close persons, Chairman of NGO Alliance of Concern in Women's Welfare (APPM), volunteers of One Heart Disability Society, staff of Office for Women's Empowerment, and Head of Women and Child Protection Unit, and medical personnel. The data were collected by in-depth interview, observation, and document review. Interactive analysis included data collection, reduction, display, and verification.

Results: The age of female victims of sexual violence ranged between 15 and 21 years. They had no schooling or junior high school education. All of them came from Sukoharjo, Central Java. The forms of sexual violence were sexual harassment and rape. The perpetrators were close persons of the victim. The biological, reproductive, and psychological impacts of the victim included fear, irritation, trauma, worry, self-imprison, self-contain, feelings of revenge, emotion, stress, pain during urination, fever, unwanted pregnancy, and complications of childbirth. The social impacts included isolation, gossiping, and negative stigma of the victim. The victim's behaviors in coping with the biopsychosocial impacts included routine medical check up, attempt to forget, taking for granted, and avoidance of bringing up the incidents of sexual violence, preoccupation with positive activities, seeking support of the close person, being more careful of the opposite sex, and avoidance of mingling with unrecognized people in a strange environment.

Conclusion: Female sexual assault cases suffered undesireable biological, reproductive, psychological, and social impacts. The impacts of biological and reproductive health take the forms of health problems, unwantted pregnancy, and complications of childbirth. There is a need for support to help overcome the biopsychosocial impacts of sexual violence victims.
\end{abstract}

Keywords: Health Belief Model, biopsychosocial impacts, sexual violence

\section{Correspondence:}

Isna Rahmawati Retnaningsih. Masters Program in Public Health, Sebelas Maret University, Jl. Ir. Sutami 36 A, Surakarta 57126, Central Java. Email: rahmawatiisna.ir@gmail.com.

Mobile: +6285640533107.

\section{BACKGROUND}

Sexual violence is an action that leads to sexual invitation/ insistence such as touching, groping, kissing or any other actions which is unwanted by the victim. In addition, the perpetrator forces the victim to watch pornography products, sexual jokes, degrading remarks, and harassing by leading to sexual aspects of the victim, until forcing the sexual intercourse without any consent from the victim. Whether it is accompanied by physical violence or not; 
compelling to conduct unwanted sexual activities, degrading, hurting, or wounding the victim (Poerwandari, 2000).

According to WHO (2002) sexual violence on women is a serious public health problem and suffered by millions of victim around the globe. Studies by WHO in several countries represent almost one of four women have experienced sexual violence perpetrated by their partners. Even one third of adult women experienced the first sexual violence during their adolescence.

According to WHO, it is found that $35 \%$ women around the globe have experienced physical and sexual violence. And the violence cases fatally affect women's health problems, one of them is $16 \%$ victims have to experience delivery with Low Birth Weight. The other impacts to health are abortion, depression, and HIV infection. Whereas sexual violence perpetrated by strangers leads to alcohol consumption, depression, and anxiety (WHO, 2013).

The rate of violence against women in Indonesia is still relatively high. National Commission on Violence against Women reported in 2015 there were 5.002 cases of violence against women in community domain. From the figure, sexual violence was in the first rank (61\%). The types of violence are rape, molestation, sexual harassment, and others (Komnas Perempuan, 2016). Meanwhile the number of cases that involve children in Indonesia is increasing each year. It is illustrated by data from Indonesian Commission on Children Protection that the reported cases of sexual violence on children were 412 in 2012, 343 cases in 2013, and increasing to 656 cases in 2014 (KPAI, 2016).

In Central Java Province, it was recorded that during 2014-2015 cases of gender and children based violence was categorized as "alert" since it indicated a relative high number, both in quantity as well as quality. The number of violence victims in 2015 was 2.630 people including adult and children. Among all cases, the most cases were sexual violence that was 846 cases. In particular for sexual violence cases in 2012 there were 7 boys and 450 gilds. In 2013 there were 16 boys as victims and 409 girls. In 2014 there was a significant increase, as there were 53 boys and 556 girls as the victims. According to PKBI Central Java there were 2 children that became the victims of sexual violence everyday (PKBI Jawa Tengah, 2016).

The phenomena of sexual violence on women are also still found in Sukoharjo, which is one of regencies in Central Java. Based on the report of the Office of Population Control, Family Planning, Women Empowerment and Children Protection ( $\mathrm{PPKB}$ and $\mathrm{P}_{3} \mathrm{~A}$ ) in 2015, there were 24 cases of sexual violence on women and children. Whereas data of 2016 showed that there were victims of 22 sexual violence cases. The data included victims who are reported either by family or community.

Sexual violence cases may generate negative impact on victims such as eating disorder (anorexia), sexual problems, selftorture, and somatic symptoms such as anxiety, trauma, destroyed self esteem, or prolonged depression (Knauer, 2002). The impact toward women who experienced sexual violence during their childhood is studied by Leeners et al., (2015). Leeners studied the child birth process on mothers with sexual violence experience during their childhood. The generated impact is there is an extra challenge to build the sense of confidence and individual integration with health workers as well as related NGO for the psychological treatment.

In addition to physical and psychological impacts, sexual violence also gives social impacts to the victims. Public tends to 
give negative label to the victims of sexual violence. The victims of sexual violence are considered as impure, sinful and disgraceful. The family of sexual violence victims consider it as a disgrace and as the result, the victim should be exiled temporarily for the family not to feel ashamed. There are a lot of sexual violence victims who are discriminated and exiled by the community (Bahri dan Fajriani, 2015; Lustanto, 2015).

The magnitude of the impact generated as the result of sexual violence imposes the victims and several parties to overcome it. Factor that influence in overcoming the impact of the violence among others are self concept, personal strength, support from the environment, and professional help from legal and medical system (Illenia, 2011). From the victims themselves, it needs an effort to recover by means of the belief or confidence to recover from the impacts they suffer from. Health Belief Model theory consists of six components namely cues to action, perceived susceptibility, perceived severity, perceived benefit, perceived barrier and self efficacy. Based on the concept the victims of sexual violence will attempt to recover or healed from the illnessses (Maulana, 2009).

Since the impact of sexual violence is tremendously big it demands various parties (the closest people, health workers, and NGO) to immediately conduct prevention efforts of sexual violence. Furthermore it has to be accompanied by healing effort as well as treatment for teenagers who have become victims of sexual violence, so that they do not suffer from prolonged trauma and are able to live a normal life. Aliansi Peduli Perempuan Makmur (APPM) is an alliance of women that receives reports on violence cases on women and children. The NGO is a place to protect and assist women and children, victims of sexual violence.
Based on the elaboration above, the researcher conducted Case Study on Biopsychosocial Impacts and Coping Behaviors among Victims of Sexual Violence against Women

\section{SUBJECTS AND METHOD \\ 1. Design of the Study \\ The study was qualitative descriptive by using case study approach method. The po- pulation was the victims of sexual violence in Sukoharjo. Subjects of the study were se- lected by using purposive sampling tech- nique.}

\section{Informants}

The informants of the study included 2 key informants, 3 main informants, and 5 supporting informants. The key informants including the Head of APPM and Sehati volunteer. The main informants were 3 victims of sexual violence. The supporting informants were parent, staff member of the Office of Women Empowerment, Women and Children Protection, the Head of Women and Children Protection Unit, and Medical Worker.

\section{Time and Place of Study Imple- mentation}

The study was conducted in June until July 2017 in Sukoharjo Regency with a consideration there was a high number of sexual violence victim among women and children in Sukoharjo even though it had been labeled as Children Friendly City. In addition, it became the object of assistance of an NGO that collaborate in the study.

\section{Instruments of the Study}

Supporting instruments of the study consisted of any relevant documents to support the interview. The document including interview guideline that contained the open questions; voice recorder; books and literatures related to material used in interview and study. 
Journal of Health Promotion and Behavior (2017), 2(3): 218-231

https://doi.org/10.26911/thejhpb.2017.02.03.03

\section{Data Analysis}

The data were collected by using in-depth interview, observation, and documentation study. Data validity was measured by using triangulation technique that was triangulation of source, method, and theory. The study used Miles and Huberman interactive model as data analysis technique that consisted of data gathering, data reduction, display and verification.

Data collection was conducted by using in- depth interview, observation and documentation study. The instruments of data collection were voice recorder, interview guidelines, observation guidelines, stationery, and laptop. The data collected were analyzed by using interactive model that included data reduction, data presentation, and conclusion making or data verification (Miles dan Huberman, 2007).

\section{RESULT}

Based on the result of the study, it was found that female informants who were managed to get interviewed were from productive age. Among others were A1 (16 year old), A2 (18 year old) and A3 (21 year old). They admitted that they had experienced sexual violence in the form of molestation and rape. The perpetrators were the closest persons and someone known by the victims. The perpetrators of sexual violence were all the closest persons of the victims such as older cousin, neighbors, and step fathers of the victims.

It was supported by the statement from $\mathrm{W}$ as the supporting informant (P2):

"Most perpetrators of the violence in Sukoharjo came from the closest persons. Whether it was friend, neighbor, relative, boyfriend even their own father" (P2, Head of Women and Children Protection Unit). The result of interview on 19 July 2017."

\section{Biopsychosocial Impact on Women who experienced Sexual Violence}

The researcher identified the impacts generated by sexual violence in term of reproductive health, biological, psychological as well as social on women who had experienced sexual violence. The following was the result of interview with informants related to the impacts endured after going through sexual violence :

"Back then, after I was sexually abused, I didn't know much. I just cried and refused to meet people. My neighbours used to talk about me each time I was going to pass by, usually I turned, and went back home. Later, during my prayer, I wished they would stop doing it. I didn't feel any health problems, it's simply usual menstrual cramp". (A1). The result of interview on 20 July 2017.

Information obtained from the main informant (A1) was supported by the result of interview with supporting informant ( $\left.\mathrm{P}_{4}\right)$ who was the closest person as well as mother of main informant (A1), that sexual violence happened to main informant (A1) had given psychological and social impact. The following was the result of interview with supporting informant ( $\left.\mathrm{P}_{4}\right)$ :

"My daughter has forgotten about the incident. She kept crying at that time, and became quiet. She is afraid of men. She rarely hang out with her friends and choose to stay at home. It seems that she feels exiled". ( $\left.\mathrm{P}_{4}\right)$ The result of interview on 17 July 2017.

The psychological and social impacts generated after experiencing sexual violence on main informant (A1) were supported by the second main informant (A2). The other impact endured was physical impact that was clearly seen on Main Informant (A2). Main Informant (A2) was more irritated and intended to take revenge to the perpetrator because of the dreadful physical 
impact onto the Informant until it made her pregnant and suffered from child birth complication.

The impact generated by sexual violence on Main Informant (A2) was also supported by a statement by Key Informant (K1) and (K2), each of them were assisting the two victims all this time. They stated that sexual violence could lead to stress, shocked as the result of the fear endured by the victims who experienced it.

"In most cases that I assist, there is behaviour change, it is frightened, and avoiding to encounter with the environment of the perpetrator.”. (K1) The result of interview on 6 July 2017.

"This is the case I assist, when I assisted A2, her hand hold my hand tightly. She was shocked and frightened. The health impact was she was pregnant and delivered a small baby." (K2) The result of interview on 17 July 2017.

The main informant (A3) revealed that there was no serious impact after she experienced sexual violence. It was only that she felt easily to get emotional, angry, and inferior. The following was her statement:

"I feel a bit calm since he is in jail. However sometimes I'm still strangely emotional". (A3) The result of interview on 29 June 2017.

Meanwhile, in different place and time, Mrs W as Supporting Informant ( $\left.\mathrm{P}_{2}\right)$ revealed that the impacts of sexual violence on victims were physical and psychological. The following was her statement:

"For under 10 year old girls usually the problems will be physical, such as it hurts for urinating, fever, feel pain all over the body,...for girls who are older than 10 years old, usually the parents realized she misses her period, they know she's pregnant. Yes, the victim (A3) felt pain during the medical check. You can read the medical report ... here you are ...”. (P2). The result of interview on 19 July 2017.

Women's Behavior in Coping Biopsychosocial Impact as the Result of Sexual Violence they Experienced

The researcher identified women behavior in coping the biopsychosocial impact generated by sexual violence they underwent. The following was a piece of an interview result conducted with the informant :

"I have forgotten the incident. Now, I choose not to hang out often with neighbours and I find my spirit from mom, dad and siblings. Now, I'd rather be active in school activities". (A1) The result of interview on 20 July 2017.

Behavior of the main informant (A1) was supported by a statement from supporting informant ( $\left.\mathrm{P}_{4}\right)$ who stated that in coping behaviour toward biopsychosocial impact, A1 tried to not to remember the incident, she'd rather be active in school activities, did not mingle with friends in her neighbourhood. She had forgiven the perpetrator, but still keep the distance from men. Furthermore, she was not dare to interact with strangers.

A1's statement was supported by the statement conveyed by main informant (A2). the behaviour conducted by main informant (A2) in coping the biopsychosocial impact generated by sexual violence she had undergone, was by not remembering it, recovering from physical impact she endured and focused on her future. It was from the statement of supporting informant ( $\left.\mathrm{P}_{5}\right)$ :

"I only can accept the fate. What more I can do. What's matter now is taking care of my daughter's future. My daughter (A2) never goes out. After we know she's pregnant, I bring her to a midwife regularly for examination. I just focus to take care of the baby". (A2) The result of interview on 30 June 2017. 
Meanwhile the behaviour conducted by main informant (A3) was a little bit different from the previous main informant that she $\left(\mathrm{A}_{3}\right)$ tried to forget and let go of the incident. However A3 still felt sad, since whats over, the perpetrator was her step father. The following was a piece of the result of the interview with the informant:

"Well, I have forgiven and forgotten. Now, I choose to stay at home by myself, but with my mom. However, I feel sad because he was my step father". (A3) The result of interview on 26 June 2017.

Internal and External Dimension to Cope with Biopsycosocial on Women who Experienced Sexual Violence

Internal dimension to cope the impact of violence by using Health Belief Model approach to identify health behaviour on informant in coping the biopsychosocial impact generated by sexual violence that had been experienced.

\section{Cues to Action}

The result of the study showed that all informants conveyed that the encouragement to behave in coping the biopsychosocial impact generated by sexual violence, came from themselves and family. In addition they also obtained the encouragement from their environment. Most of the informants obtained encouragement from the closest people, since the closest people who always stayed by their side after the incident of sexual violence.

\section{Perceived Susceptibility}

The researcher identified victims' perceptions on the level of susceptibility sensed after conduct behavior change to cope the impacts generated by sexual violence. All female victim informants stated that there was no susceptibility sensed after they implemented behavior in coping the biopsychosocial impacts as the result of sexual violence they had undergone. There was a victim informant who stated that if she did not implement the coping behavior to overcome the biopsychosocial impact, then she would experience more severe violence and impact. The following was the result of interview conducted with the informant:

"Well, I always be optimistic now..it will never happen again. I can take care of myself and forbidden to go anywhere by my mother..”. (A1) The result of interview on 17 July 2017.

\section{Perceived Severity}

Victims' perception on the severity sensed if did not behave in coping biopsychosocial impact as the result of sexual violence they experienced:

"It must be forgotten, we should never remember it. If I always think about it I cannot move on, yet I have my own dream". (A1) The result of interview on 17 July 2017.

Main informant (A2) thought that if she did not unleash and let go the incident of sexual violence she experienced, then she would be stressful and frightened. Even though it was not easy to forget because of the heavy burden she carried, which was pregnancy and a child. The main informant (A3) thought that she would get absurdly emotional if she did not forget the incident of sexual violence she experienced.

\section{Perceived Benefit}

Victims's perception on the benefits sensed after they implementing coping behavior to overcome biopsychosocial impacts generated by sexual violence they experienced. It was similar main informant (A2), that by forgetting the incident then the benefit she obtained was no more overthinking and frightened. In addition, since the impact was significant, the informant (A2) thought it was very important and beneficial for her and her health. The following was a piece of the result of interview with the informant:

"I think, it will be beneficial for me if I forget the incident and start to get my 
medical examination regularly". (A2) The result of interview on 30 June 2017.

Supporting informant also had the same perception. By forgetting and getting medical examination, soon she will overcome the impacts.

\section{Perceived Barrier}

The researcher identified victim informants' perception on barrier that was sensed during implementing coping behavior toward biopsychosocial impacts generated by sexual violence they experienced. Some women informants stated that they did not find barriers when they implemented coping behavior to overcome biopsychosocial impacts as the result of sexual violence they experienced. However there was one informant that still felt difficult and there were barriers in raising the baby. Main informant (A2) through $\mathrm{P}_{5}$ found barriers when she implemented coping behavior toward the impacts of sexual violence since she found it difficult to take care of her baby for the limitation of motion:

"I'm confused on how to take care of the baby and how I can afford it". ( $\left.\mathrm{P}_{5}\right)$ The result of interview on 21 July 2017.

\section{Self Efficacy}

Self efficacy of each woman informant to recover from biopsychosocial impacts generated by sexual violence she had experienced. The result of the interview conducted to all women informant stated that all informants believed that they were able to recover from biopsychosocial impacts generated from sexual violence they have experienced.

Although there was informant who was a bit difficult in coping the social economy impact, thus she was still establishing the belief to cope the economy impact:

"At the beginning I was not so sure...but since there were a lot of who wanted to help, so I managed with it..." (A3) through P5. The result of interview on 21 July 2017.
Self efficacy of all street children informant was also supported by the opinion of head of Women and Children Protection Unit who handle sexual activity:

"Most of the cases were settled amicably with diversion, legal process outside the court. After the problem was clear, later victims and family would slowly recover and accept it“. (P2) The result of interview on 19 July 2017.

In addition to internal dimension of behavior change, the researcher indentified the existence of external dimension of the victims in coping the biopsychosocial impacts. All informants of sexual violence victims obtained positive external support to cope the biological, psychological, social and health reproductive impacts:

"For me the biggest support comes from my mom and dad. They are my refuge, and also my uncles and aunty. They said "It's ok, be patient. It is probably a trial from Allah". Besides from family, there is also from other people. A lady from APPM, the lawyer, psychiatrist, and from the children protection, it makes me feel more confident". (A1) The result of interview on 17 July 2017.

The statement from the informant was supported by key informant who was the closest person of the victim. The support was provided for the victim to be able to cope the impact and face negative stigma from the community:

"I was the first who assisted, since the victim was villager, she did not understand. At first I brought the two families to come to settlement. I told the family of the victim and perpetrator to settle it coldheaded". (K1) The result of interview on 6 July 2017.

"We assisted the family, but we could not interfere. Since the settlement decision was purely from the victim and related 
Journal of Health Promotion and Behavior (2017), 2(3): 218-231

https://doi.org/10.26911/thejhpb.2017.02.03.03

families" (K2). The result of interview on 18 July 2017.

Support for victims to be able to cope the biopsychosocial impacts was given by the closest people, assistant, also by medical personnel, PPKB \&P3A and PPA Unit. The following were the statements :

"There is an assistance from us. At the moment we have personnel in every subdistrict, it is called integrated service post. It is located in the office of sub-district". (P1). The result of interview on 18 July 2017.

"We receive the report, and we follow them whether the case is going to be followed up or not From PPA unit we have medical check and psychiatrist is available

Table 1. The impacts of sexual violence and behaviours in coping the impacts on women who experienced sexual violence in Sukoharjo

\begin{tabular}{|c|c|c|c|c|c|}
\hline \multicolumn{4}{|c|}{ Characteristics of Victims and Perpetrators } & \multirow[b]{2}{*}{$\begin{array}{c}\text { Coping } \\
\text { Behaviors }\end{array}$} & \multirow[b]{2}{*}{$\begin{array}{l}\text { External } \\
\text { Support }\end{array}$} \\
\hline $\begin{array}{l}\text { Forms of } \\
\text { Violence }\end{array}$ & $\begin{array}{l}\text { Perpetra } \\
\text { tors }\end{array}$ & $\begin{array}{l}\text { Motivation } \\
\text { of the } \\
\text { Perpe- } \\
\text { trator }\end{array}$ & $\begin{array}{c}\text { Impacts of Sexual } \\
\text { Violence }\end{array}$ & & \\
\hline $\begin{array}{c}\text { Sexual } \\
\text { Harassment, } \\
\text { Rape, Sexual } \\
\text { Harassment }\end{array}$ & \begin{tabular}{l}
\multicolumn{1}{c}{ Cousin } \\
Neighbor \\
Step \\
father
\end{tabular} & $\begin{array}{l}\text { Porn video } \\
\text { Inharmonio } \\
\text { us family } \\
\text { Inharmonio } \\
\text { us family }\end{array}$ & $\begin{array}{l}\text { Physical and Health } \\
\text { Reproductive Impact } \\
\text { Heavy menstrual pain, } \\
\text { nausea, vomiting, } \\
\text { amenorrhea, } \\
\text { Unwanted pregnancy, } \\
\text { PPROM, LBW, Fever, } \\
\text { Painful urination, } \\
\text { vaginal fissures } \\
\text { Psychological } \\
\text { Impacts } \\
\text { Emotional, upset and } \\
\text { anxious, afraid, } \\
\text { ashamed, } \\
\text { uncommunicative, } \\
\text { difficult to get along } \\
\text { Social Impacts } \\
\text { Exiled, negative stigma, } \\
\text { do not mingle with } \\
\text { neighbors }\end{array}$ & $\begin{array}{l}\text { 1. Forgetting the } \\
\text { incident } \\
\text { 2. Reducing } \\
\text { interaction } \\
\text { with } \\
\text { neighbours } \\
\text { 3. Praying } \\
\text { 4. Hanging out } \\
\text { with friends at } \\
\text { school } \\
\text { 5. Be active in } \\
\text { school } \\
\text { activities } \\
\text { 6. Letting go } \\
\text { 7. Regular } \\
\text { medical check } \\
\text { up } \\
\text { 8. Not going out } \\
\text { often. }\end{array}$ & $\begin{array}{ll}\text { 1. } & \text { Family } \\
\text { 2. Peers } \\
\text { 3. Assistance } \\
\text { by APPM } \\
\text { 4. "Sehati" } \\
\text { volunteer } \\
\text { 5. Medical } \\
\text { personnel } \\
\text { 6. Psychiatrist } \\
\text { 7. Office of } \\
\text { PCFP \&P3A } \\
\text { 8. WCP Unit }\end{array}$ \\
\hline
\end{tabular}

\section{DISCUSSION}

Sexual violence on women becomes one of the public health problem phenomena which is serious and experienced by millions of victims all over the world. From seve- to help the victim." (P2). The result of interview on 18 July 2017.

Support for the victims to be able to overcome the impact of sexual violence came from various parties. However, in addition to what came from the authorities, the other parties were also needed such as from Education Office and schoolmates/ peer. As it was conveyed in the following statement:

"I guess, there should be a support from Education Office, since the victims and perpetrators are children, and often rejected at school. Instead, they should be protected". (P2). The result of interview on 18 July 2017. 
With different backgrounds, a lot of studies in various countries related to sexual violence on women including children and adolescence, find significant number of incidences.

WHO conducted Global Systematic Review that studied sexual violence by spouses and by other unknown people. From the global review it found that 35\% women around the world have experienced physical and sexual violence. And from the sexual violence case resulting fatal impacts to women health problems, one of them is $16 \%$ victims of sexual violence undergo child birth with low birth weight. The other health impacts were abortion, depression and HIV. Meanwhile, women who experienced sexual violence perpetrated by other unknown people are lead to alcohol abuse, depression and anxiety (WHO, 2013).

Sexual violence endured by children and adolescents also has significant rate. studies in various countries in particular discuss sexual violence on children with its own terminology that is Child Sexual Abuse (CSA). A study conducted by Barth et al., (2013) by using systematic review method and meta-analysis from 55 studies through 24 countries showed the result that prevalence of sexual violence on children are 8$13 \%$ happen to girls and $3-17 \%$ happen to boys. The study showed that sexual violence happen more to girls compare to boys.

In addition to female especially adolescents and children, the group that is susceptible to the act of sexual violence is the disabled people. Women with disabilities are likely to be easier to experience sexual violence compare to other women since the perpetrator thinks that disabled women are relatively powerless to refuse. Furthermore, sexual violence on disabled is probably easier to be manipulated so that violence may occur, the perpetrator also thinks that women with disabilities will not report the attack they undergo (Martin et al, 2006).

Devries et al., (2014) states that disabled children are 3 until 4 times more at risk for experiencing violence including sexual violence compare to non-disabled children.

The main informants of the study who became victims in average were female adolescents and also disabled. Victims had different background of age, had almost similar educational background and social economy. The age of Main Informants A1, $\mathrm{A} 2$, and $\mathrm{A} 3$ respectively was 16 year, 18 year, and 21 year. The forms of sexual violence experienced by each informant were varried. Two informants experienced sexual harassment in form of molestation. While one informant experienced rape.

The perpetrators of sexual violence addressed in the study were the closest people of the victims. Among others were older cousin, neighbor, and step father of the victim. It is in accordance with the theory stated by Murdiyanto (2015), 100\% of sexual violence perpetrators are people well known by the victims, such as neighbor, sibling, relative, teacher, grandfather and even biological father of the victims.

The impacts of sexual violence come in the form of biological, health, reproductive, physical and social. In the study, the inflicted physical impacts on all informants were varied. And when victims feel bigger physical impacts, it needs bigger behaviour change effort also.

The physical or biological impacts inflicted by sexual violence that were experienced by the informants were: vaginal pain, painful urination, the feeling of fever, excessive menstrual pain more than usual, unwanted pregnancy, and child birth with complications. 
Journal of Health Promotion and Behavior (2017), 2(3): 218-231

https://doi.org/10.26911/thejhpb.2017.02.03.03

Informant A1 stated that the health problems she felt was the excessive menstrual pain. While $A_{3}$, she endured pain during urinating, and the feeling of fever. The greatest impact was endured by A2 since she was pregnant and delivered with complication, it was premature rupture of the membrane. It was confirmed by the result of medical checkup by doctor in WCP Unit, Sukoharjo, that there were wounds in the victim's hymen.

Biological and reproductive health impacts on the victims of sexual violence are similar with what stated by BKKBN and UNESCO (2012) the physical trauma as the impacts of sexual violence is in the form of body organ damage such as muscle tissue, soft tissue trauma, and physical trauma of outer body parts such as hematoma, wounds, fever and other impacts. Meanwhile the impacts on reproductive health, in particular are revealed by . Taft AJ, et al (2015) on women of reproductive age, among others are ruptured hymen, genital trauma, sexual transmitted diseases (STD), HIV, pregnancy termination, problems of the minimum antenatal visits, the poor infant's health status up to fetus death.

There was an informant who endured the impact of child birth with Premature Rupture of Membrane. The impact of child birth complication is in accordance with a study by Montgomery (2015). Montgomery explains the possibility on trauma that causes pregnanct and child birth complication. WHO explains the psychological trauma that may impact on stress up to prenatal and maternal health namely Low Birth Weight, prematurity and abortion.

Psychological impacts experienced by victims are fear, uncommunicative, upset, emotional, anxiety and stress. The level of severity of psychological impact greatly depends on several matters, such as the duration of the incident happened, physical impact endured and environment. The main informant with heavy physical impacts was likely to have psychological impact that was also heavier.

The result of a study by Wardhani and Weny (2011) also conveyed that the psychological impact of victim are guilt, fear, anxiety, shamefulness, anger, and hopelessness. Long term stress is a particular psychological symptom that is felt by victims as a trauma. Specifically, Fuadi (2011) discusses about PTSD or Post Traumatic Stress Disorder. PTSD usually appears on victims of sexual violence during 30 days post the incident. Therefore the assistance toward rape victims is absolutely needed. The rape victims may obtain social support from friends, parents, relative, psychologist, or anybody who is able to listen their complaints and does not judge the victim. It is important to grow the feeling of confidence toward other people.

Subsequently, sexual violence experienced by the victims may give social impact to the victims. In the study, social impacts felt by the victims were negative stigma, being exiled, and afraid. Victims were often felt isolated and obtained various stigma from society. Finkelhor and Browne (1985) state that stigmatization will result different feeling based on the belief that no one else have had the experience and other people will turn down someone who experienced sexual violence.

Therefore, to cope the impact endured, there is an internal dimension to overcome in the form of behavior change. Behavior is a response toward stimulus that causes informant to act. All victim informants stated that to cope the biopsychosocial as the result of sexual violence they experienced they behaved by forgetting, letting go, and not talking about it so that they did not remember the sexual violence incidents. In addition to forgetting, there was victim in- 
formant who asked for advice from parents and closest people. And then diverted to positive things, hung out more often with school mates, kept distance from men and be alert to people newly known and suspicious.

The behaviour was conducted by all victim informants to get rid of trauma, anger, upset, and fear appeared from the sexual violence they experienced. It is in line with McPherson et al., (2012) who stated that behaviour therapy may reduce as well as prevent the level of severity and duration of acute psychological disorder on the victims of sexual violence. Wilson (2006) also stated that the trauma healing effort conducted by the victims of sexual violence is not able to forget or get rid of bitter experience they obtain. Instead, the trauma healing effort is only to reduce stress endured by the victims and also to gain control over their life in order not to keep on feeling guilty and ashamed.

Health behaviour was studied in the study by using Health Belief Model. The theory is a determinant model of helath behaviour mostly used in education and health promotion. In the concept of Health Belief Model (HBM) it is explained that one's health behaviour may get influenced by individual's own belief or perception on certain disease (Rawlett, 2011).

Health behavior conducted by informants to cope the impact of sexual violence was good already, referring to HBM theory. One component for example is cues for action conducted by informants because of the impulse from their understanding, the size of the impact and encouragement of the closest people. The victims immediately conducted behaviour of having medical checked up, reporting the incident and performing healing effort of trauma by forgetting and letting go. The similar thing studied by Illenia \& Handadari (2011) that the victims of sexual violence need great support from their own belief, friends and family to perform the effort in coping the impact of sexual violence.

Meanwhile, perceived susceptibility, perceived severity, and perceived benefit of the informant in general were similar. Each informants felt it is necessary, beneficial to conduct health behaviour by checking her health condition in health facility to get healed from biological and reproductive impacts. In addition, to recover psychologically, they forget the incident and divert by doing positive activities for themselves.

The severity that can be observed from the impact of sexual violence is child birth with complication endured by one of the informants. It is elaborated by a study conducted by Leeners (2015) who studied about the impacts of sexual violence that have been experienced in youth affects on the child birth complication, therefore it needs to establish the feeling of confidence and individual integration with health workers as well as NGO. Whereas the benefits of coping behaviour toward the impact of sexual violence related to psychological tretament, WHO (2003) states that the effort or treatment on the victims of sexual violence cases may improve quality of life and quality of support given to them. Therefore it is beneficial for the informants.

The subsequent component is barrier to act. Barriers can be in the form of unpleasant feeling or pain during treatment, the feeling of rejected, in addition, barriers can be in the form of cost either in term of monetary cost (medical cost) or time cost (the time used during the treatment as well the time used to go to health facility that is considered reducing productivity). It is a determinant factor contributes in Health Belief Model (Becker \& Rosenstock et al, 1988). 
Journal of Health Promotion and Behavior (2017), 2(3): 218-231

https://doi.org/10.26911/thejhpb.2017.02.03.03

Based on the result of the study it was found that the informants faced no barrier to conduct behavior change. However, there was one informant who faced financial barrier in the effort of recovery. Therefore it needed support from relatives, environment and NGO to be able to perform healing effort from the disease and recover from her trauma.

In addition to internal dimension, it needs the occurrence of external dimension that support the victims to overcome biopsychological impacts as the result of sexual violence. In this study generally it came from the closest people, family, friends, and outside parties who contributed. Outside parties could be anyone who contributed in helping the victims such as NGO, medical personnel, WCP Unit, neighbours, and the village officials who cared for.

Informants who reported and looked for assistance form NGO on Women in Sukoharjo, which was APPM, would get support from the beginning until the victims underwent legal process or chose amicable way. It was quite similar with the disabled informant who found assistance in "Sehati" community, she was also assisted up to the case was settled. It I srelevant with the statement of WHO (2013) the effort in to overcome the impacts on female victims of sexual violence was conducted in various stages such as personal counselling, medical assistance, social assistance, and legal assistance. Therefore, in the end the victim is able to cope the impacts more easily.

The barrier sometimes found is the society condition that still gives negative stigma to the victims, moreover, if the case is brought to court. Therefore social assistance is also an important part in external dimension so that victims can recover soon from the biopsychosocial impacts of sexual violence.
REFERENCE
$\overline{\text { Bahri S, Fajriani (2015). Suatu Kajian Awal }}$ terhadap Tingkat Pelecehan Seksual di Aceh. Jurnal Pencerahan. 9(1): 50- 65 .

Barth J, Bermetz L, Heim E, Trelle T (2013). The Current Prevalence Of Child Sexual Abuse Worldwide: A Systematic Review And Meta-Analysis. International Journal of Public Health 58, 469-483.

Becker HM, Rosenstock I (1987). The Health Belief Model and Personal Health Behaviour. Slack Inc: New Jersey.

BKKBN (2012). Buku Suplemen Bimbingan Teknis Kesehatan Reproduksi Pelecehan Seksual. Jakarta: BKKBN. $\mathrm{Jak} / 2013 / \mathrm{PI} / \mathrm{H} / 28$.

Devries KM, Kyegombe N, Zuurmond M, Parkes J, Child JC, Walakira ED, Naker D (2014). Violence Against Primary School Children With Disabilities In Uganda: A Cross-Sectional Study. BMC Public Health 14:1017.

Finkelhor D, Browne A (1985) The Traumatic Impact of Child Sexual Abuse: A Conceptialization. Durham: University of New Hampshire.

Illenia P, Woelan H (2011). Pemulihan Diri Pada Korban Kekerasan Seksual. Jurnal INSAN Universitas Airlangga. 13(2).

Komnas Perempuan (2016). Kekerasan Terhadap Perempuan Meluas: Mendesak Negara Hadir Hentikan Kekerasan Terhadap Perempuan Di Ranah Domestik, Komunitas Dan Negara. Lembar Fakta Catatan Tahunan (Catahu) 2016. http://www.komnasperempuan.go.id. Diakses pada 10 Januari 2017.

KPAI (2016). Bank Data KPAI Tentang Angka Kekerasan Pada Anak 20122014. Komisi Perlindungan Anak 
Indonesia. http://www.bankdata.kpai.go.id. Diakses pada 28 Desember 2016.

Leeners B, Gisela G, Emina B, Michael PH (2015). Birth Experience In Adult Women With A History of Childhood Sexual Abuse. Journal of Psychomatic Research; 83 (2016) 27-32.

Martin, SL, Ray N, Alvarez DS, Kupper LL, Moracco KE, Dickens PA, Scandlin D, Gizlice Z (2006). Physical and Sexual Assault of Women With Disabilities. SAGE Journals Online and High Wire Press platforms. 12 : 823-837.

Maulana H (2009). Promosi Kesehatan. Jakarta: EGC.

McPherson, Scribano P, Steven J (2012). Barriers to Successful Treatment Completion in Child Sexual Abuse Survivors. Journal of Interpersonal Violence. 27(1):23-39.

Miles MB, Huberman AM (2007). Analisis Data Kualitatif. Jakarta: UI Press.

Montgomery, E, Chatherine P, Jane R (2015). A Feminist Narrative Study Of Maternity Care Experiences Of Women Who Were Sexually Abused In Childhood. Midwifery International Journal. 31 (2015):54-60.

Murdiyanto (2015). Darurat Kekerasan Seksual Anak. Yogyakarta: $\mathrm{B}_{2} \mathrm{P}_{3} \mathrm{KS}$ Press.

PKBI (2016). Nyala Lilin Untuk Para Korban: Selasa, 24 Mei 2016. Perkumpulan Keluarga Berencana Indonesia. www.pkbijateng.or.id. Diakses pada tanggal 7 Februari 2017

Poerwandari EK (2000). Kekerasan Terhadap Perempuan: Tinjauan Psikologi
Feministik. Jakarta: Kelompok Kerja "Convention Watch" Pusat Kajian Wanita dan gender. Universitas Indonesia. Diakses 29 Desember 2016.

Rawlett K (2011). Analytical Evaluation of the Health Belief Model and the Vulnerable Populations Conceptual Model Applied to a Medically Underserved, Rural Population. International Journal of Applied Science and Technology; 1(2): 15-21.

Taftn AJ, Rhonda L, Lyndsey FW (2015). The Impact Of Violence Against Women On Reproductive Health And Child Mortality In Timor-Leste. Australian And New Zealand Journal Of Public Health. 39: 177-181.

Wardhani YF, Weny L (2011). Gangguan Stres Pasca Trauma pada Korban Pelecehan Seksual dan Perkosaan. Pusat Penelitian dan Pengembangan Sistem dan Kebijakan Kesehatan Surabaya.

Wilson KA (2006). Sexual Assault and Posttraumatic Stress Disorder: A Review of The Biological, Psychological and Sociological Factors and Treatments. Journal of Medicine, 9(2): 11-118.

WHO (2003). Chapter 6: How is sexual violence defined?. World Report on Violence and Health: page 149. http://www.who.int. Diakses pada 10 Januari 2017

(2013). Global And Regional Estimates of Violence Against Women: Prevalence And Health Effects Of Intimate Partner Violence And Non Partner Sexual Violence. Italy: WHO Press. 